\title{
Richter-transzformáció sikeres kezelése célzott hatásmechanizmusú szerekkel
}

\author{
Successful treatment of Richter syndrome \\ with targeted drugs
}

\author{
Szász Róbert ${ }^{1, @}$, Radnay Zita $^{1}$, Telek Béla ${ }^{1}$, Molnár Sarolta $^{2}$, Illés Árpád ${ }^{1}$

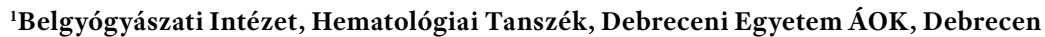 \\ ${ }^{2}$ Pathológia Intézet, Debreceni Egyetem ÁOK, Debrecen
}

(Beérkezett: 2019. július 8.; elfogadva: 2019. szeptember 18.)

\begin{abstract}
A krónikus limfoid leukémia kezelése az utóbbi évtizedben jelentős változáson ment keresztül. A sikeresebb gondozás következtében a betegek túlélése nő, azonban ezzel egy időben a Richter-transzformáció kialakulását is gyakrabban figyelhetjük meg. A Richter-transzformáció kezelése a mai napig nem megoldott. Különböző betegcsoportokban az átlagos túlélés 9-77 hónap között van, de novo, kezeletlen CLL-ben hosszabb, az előkezelt CLL esetén hosszú távú túlélésben a betegek kevesebb mint 10\%-a bízhat [1]. Az új, célzott terápiák beillesztése a Richtertranszformáció kezelési stratégiájában kézenfekvő terápiás próbálkozás.
\end{abstract}

Egy 65 éves férfi betegünk kórtörténetét ismertetjük, akinél Richter-transzformáció jelentkezett, melynek kapcsán obinutuzumab, venetoclax és duvelisib kombinációjával sikerült remissziót elérni.

A beteg megelőző kórtörténetében hipertónia, vesekövesség, prosztatahiperplázia és kolecisztektómia szerepel. 2013 februárjában generalizált limfadenomegália hátterében a perifériás vérből készült áramlási citometria típusos CLL-t igazolt alacsony ZAP70 és CD38 expreszszióval.

Első vonalbeli kezelése 2013 márciusában indult, kezelését Rai II stádiumban masszív, progresszív limfadenomegália és B-tünetek indokolták. A FISH-vizsgálata $11 \mathrm{q}$ deléciót igazolt $87 \%$-ban. Egyéb vizsgálatai eltérés nélküliek voltak, így a kemoimmunoterápiának ellenjavallata nem volt. Per os FCR-kezelést kapott teljes dózisban. Négy ciklus után komplett remisszió mellett jelentős neutropéniás láz jelentkezett. A neutropénia rendeződése után perifériás vérből MRD-vizsgálat történt, mely negatív volt, így a terápiát kezelőorvosa felfüggesztette.

2017 szeptemberében Rai IV stádium, splenomegalia, B-tünetek miatt ismételt kezelési indikáció jelentkezett.
Trombocitopéniája szteroid mellett progrediált, 10 G/l-re csökkent.

Köhögés és mediasztinális limfadenomegália jelentkezett infektív jelek nélkül. 2019 októberében sikeres szűrővizsgálatot végeztünk az ACE-CL-006 tanulmányba, ahol az acalabrutinib karba került.

A kezelés előtt végzett kiterjedt prognosztikai vizsgálatok komplex karyotípuseltérést, $11 \mathrm{q}$ deléciót, $13 \mathrm{q}$ deléciót és SF3B1-mutációt igazoltak. Az $I G H V$ szomatikusan nem volt mutált, TP53-mutáció vagy deléció, $6 \mathrm{q}$ deléció, 12-es triszómia, NOTCH1-vagy MYD88-mutáció nem igazolódott, CD38-pozitivitás nem volt jelen. Karyotípusa 45-46, X, -Y, -8, i(8)(q10), add(8)(p11.2), $\operatorname{inv}(9)(\mathrm{p} 22 \mathrm{q} 22), \operatorname{del}(11)(\mathrm{q} 21 \mathrm{q} 23), \operatorname{add}(13)(\mathrm{p} 11.2),+\operatorname{add}(13)$ (q34), $\operatorname{add}(14)(q 32), \operatorname{add}(18)(q 21),+\operatorname{mar}[c p 16]$ volt.

2017 novemberében tanulmány keretei között $2 \times 100 \mathrm{mg}$ acalabrutinibkezelés indult. Az ingerköhögés miatt tüdőgyógyászati kivizsgálást kezdeményeztünk, ami tüdőtumort nem igazolt. Fejfájás miatt metasztázis kizárására készült koponya-CT is negatívnak bizonyult (a fejfájás az acalabrutinib korai mellékhatásának volt tartható, mely rendszerint 2-3 hét alatt szünik).

A három hónap múlva végzett kontrollvizsgálat alapján betegsége komplett remisszióba került, amit CT is megerősített, de csontvelő-biopszia és MRD-vizsgálat nem történt.

Az újabb 3 hónapos kontroll során vérképe továbbra is eltérés nélküli volt, de axillaris nyirokcsomók jelentek meg, így felmerült a progresszió lehetősége, mely újabb két hónap múlva egyértelmüvé vált. Fáradékonyság, jelentős verejtékezés, ismételt köhögés mellett a laborokban 19 G/l fehérvérsejtszámot, mérsékelt anémiát és 17 G/l trombocitaszámot észleltünk, az LDH 967 U/1 volt. Hematológus által vizsgált csontvelői kenetben

\footnotetext{
@ Levelezési cím: Szász Róbert, Belgyógyászati Intézet, Hematológiai Tanszék, Debreceni Egyetem ÁOK, 4032 Debrecen,

Nagyerdei krt. 98.; Tel.: +36-52-411-600/57126; E-mail: szaszr@med.unideb.hu
} 


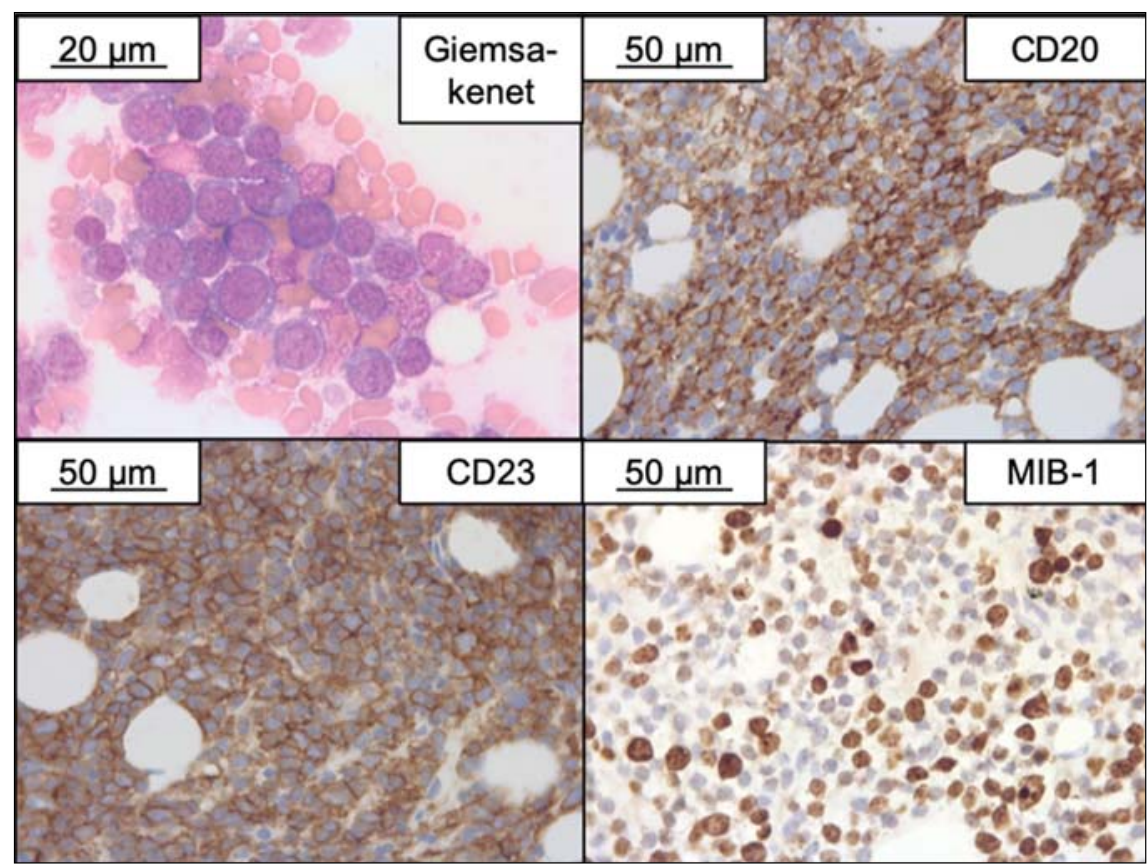

1. ábra. A kifejezetten sejtdús csontvelő-biopsziás mintában a normál vérképző állomány háttérbe szorult. A csontvelői sejtek 90\%-át középnagy-nagy sejtekből álló diffúz lymphoid proliferátum teszi ki. A sejtek magja nagy, a kromatin durván és egyenetlenül diszpergált. Immunhisztokémiai vizsgálatokkal az infiltráló sejtek CD20, CD23 és az ábrán fel nem tüntetett CD5 markerrel is pozitívak. MIB-1 proliferációs markerrel a festődési index $40 \%$. Diagnózis: Krónikus lymphoid leukaemia csontvelői infiltrációja agresszív (Richter-) transzformáció jeleivel

100\%-os CLL-es infiltráció látszott, melyet az áramlási citometria is megerősített, de felvetette $4 \%$-ban éretlen sejtek jelenlétét is, ami kezdődő Richter-transzformáció mellett szólt.

2018 júniusának végén venetoclaxkezelést indítottunk. A tumor lízis monitorozása és prevenciója mellett a gyógyszer feltitrálása 4 nap alatt megtörtént 100 mg-ra. A kezelés hatására a limfocitózis megszűnt, de a neutropénia és trombocitopénia nem javult, az anémia súlyosabbá vált. A beteg napi rendszerességgel vörösvérsejt- és trombocitatranszfúzióra szorult. A venetoclax 3 hetes szedése után ismételt csontvelővizsgálatot végeztünk, hogy a gyógyszertoxicitást, illetve a progressziót elkülöníthessük. Csontvelő-biopszia során a sicca csontvelő és a csonthenger lenyomata már valószínüsítette a transzformációt, melynek a tartósan fennálló magas LDH és B-tünetek is megfeleltek. A végleges eredmény megérkeztéig venetoclaxkezelését felfüggesztettük.

A csontvelö-bioptátum szövettani vizsgálata Richtertranszformációt igazolt (1. ábra). (Megjegyezzük, hogy a DLBCL típusú Richter-transzformáció és az agresszív CLL szövettani elkülönítése még a legújabb ajánlások mellett sem egyértelmü.)

A beteg ekkor nagyon elesett állapotban volt, neutropénás láz, felső légúti infekció súlyosbította a jelentős pancitopéniáját, transzfúziós igényét. A beteg az egyébként javasolt kemoimmunoterápiára nem volt alkalmas, így célzott kezelések kombinációját tartottuk biztonságosabbnak. A venetoclax PI3K-inhibitorral leírt potenciális szinergizmusa miatt venetoclax, duvelisib és obinu- tuzumab kombinált kezelést kezdtünk. A venetoclaxot ismét gyorsan titráltuk $200 \mathrm{mg}$-ig, a duvelisibet az ajánlott $2 \times 25 \mathrm{mg}$ dózisban, az obinutuzumabot három egymást követő héten 1000 mg dózisban kapta.

A kezelés hatására a beteg szupportációs igénye csökkent, általános állapota, közérzete javult. Két hét múlva a trombocitaszáma drámaian emelkedett, néhány nap múlva emittálható volt. A venetoclax dózisát tovább emeltük 400 mg-ra, a duvelisibkezelését összesen 6 héten át kapta.

A kontrollvizsgálatok alapján betegsége remisszióba került. Két hónappal a hazaengedése után készült csontvelői MRD-vizsgálata negatív lett. A remisszióban általában indokolt autológ ôssejt-transzplantációba a beteg akkor nem egyezett bele. Az utólag elkészült BTK rezisztenciavizsgálat C481S-mutációt igazolt.

Az eset kiemelhető tanulságai a következők:

- A klasszikus prognosztikai markerek alapján rossz prognózisú betegek (11q- és $I G H V$-U) esetében az FCR-kezelés után megfigyelt 50 hónap kezelésmentes periódus az irodalmi adatoknak megfeleló.

- A második vonalbeli vizsgálatok további rossz prognosztikai markereket találtak: SF3B1-mutáció és komplex kariotípus. Ha csak a klasszikus markereket tekintjük a 13q deléció $11 \mathrm{q}$ delécióhoz társulva nem jelez jó prognózist.

- Az SF3B1-mutáció a CLL driver mutációja, de a Richter-transzformáció gyakoriságát nem növeli [2]. Ugyanakkor ibrutinib után kialakult Richter-transzformáció esetén egy vizsgálatban 67\%-ban mutattak ki $S F 3 B 1$ génmutációt [3]. 
- A BTK-inhibitorok mellett megjelenő Richter-transzformáció gyakori predilekciós helye a csontvelö [4].

- Acalabrutinibkezelés mellett az első leírt hazai BTKrezisztencia, mely nem különbözik az ibrutinibkezelés mellett jelentkező leggyakoribb BTK C481S-mutációtól.

- A duvelisib hatékonyságát a reziduális CLL sejtekre a $B T K$-rezisztencia magyarázhatja, hiszen a $P I 3 K$-inhibitorok hatékonyak lehetnek $B T K$-rezisztencia esetén.

- A célzott kezelések additív hatása, illetve szinergizmusa a Richter-kompartment eradikációját lehetővé tette.

- A $P I 3 K$-inhibitorok a sejtes vizsgálatok alapján csökkentik az antiapoptotikus, illetve növelik a proapoptotikus fehérjék mennyiségét ( $B C L X L, M C L 1, B F L-1$, ill. $H R K, B I M)$. A venetoclax a $P I 3 K / A K T$ tengely fokozott működését okozza, mely menekülési útvonalat jelent a sejt túléléséhez. Ez az „escape” mechanizmus PI3K-gátlóval ellensúlyozható $[5,6]$.

Nyilatkozat: A kézirat más folyóiratban korábban nem jelent meg, és más folyóirathoz beküldésre nem került. A levelező szerző elolvasta a Hematológia-Transzfuziológia szerzői útmutatóját.

Érdekeltségek: A szerzőknek a közleményhez kapcsolódó közvetlen érdekeltségeik nincsenek.
Anyagi támogatás: A szerzők a közlemény megírásához anyagi támogatásban nem részesültek.

Szerzői munkamegosztás: Sz. R.: A közlemény struktúrájának megtervezése. Sz. R., R. Z., T. B., M. S.: A kézirat elkészítése. I. Á.: A kézirat ellenőrzése. A cikk végleges változatát valamennyi szerző elolvasta és jóváhagyta.

\section{Irodalom}

[1] Lenartova A, Randen U, Johannesen TB, et al. Richter syndrome epidemiology in a large population based chronic lymphocytic leukemia cohort from Norway. Cancer Epidemiol. 2019; 60: 128133.

[2] Rossi D, Spina V, Gaidano G. Biology and treatment of Richter syndrome. Blood 2018; 131: 2761 LP - 2772.

[3] Kanagal-Shamanna R, Jain P, Patel KP, et al. Targeted multigene deep sequencing of Bruton tyrosine kinase inhibitor-resistant chronic lymphocytic leukemia with disease progression and Richter transformation. Cancer 2019; 125: 559-574.

[4] Innocenti I, Rossi D, Trapè G, et al. Clinical, pathological, and biological characterization of Richter syndrome developing after ibrutinib treatment for relapsed chronic lymphocytic leukemia. Hematol Oncol. 2018; 36: 600-603.

[5] Guerrero-Hernandez M, Matas-Cespedes A, Serrat N, et al. Idelalisib interferes with the crosstalk of follicular lymphoma and its immune microenvironment and potentiates the activity of ABT199. Blood. 2017; 130: 2813 LP - 2813.

[6] Pham L V, Huang S, Zhang H, et al. Strategic therapeutic targeting to overcome venetoclax resistance in aggressive B-cell lymphomas. Clin Cancer Res. 2018; 24: 3967 LP - 3980.

A cikk a Creative Commons Attribution 4.0 International License (https://creativecommons.org/licenses/by/4.0/) feltételei szerint publikált Open Access közlemény, melynek szellemében a cikk bármilyen médiumban szabadon felhasználható, megosztható és újraközölhető, feltéve, hogy az eredeti szerző és a közlés helye, illetve a CC License linkje és az esetlegesen végrehajtott módosítások feltüntetésre kerülnek. (SID_1) 